\title{
Islam's Encounter with English and Ismail al-Faruqi's Concept of Islamic English: A Postcolonial Reading
}

\author{
Md. Mahmudul Hasan
}

\begin{abstract}
In the past, many Muslims maintained strong reservations about using English as a means of communication, interaction, and intellectual practices mainly due to its association with British colonialism. In the postcolonial world Muslims and other religious communities, as well as various ethnic and indigenous groups, have moved away from the ideological and political assumptions of a binary relationship between English and their cultural and religious identities. As a result, several hundred million Muslims now use English as their first or second language, and more books on Islam are published in it than in any other language. However, Ismail al-Faruqi (1921-86) sees a serious anomaly in how Muslim names and Islamic theological terms are transliterated and translated, as the dominant practice shows not a loyalty to meaning, but to the norms of the target language. Such an approach causes these names and terms to lose semantic associations and religious connotations. To rectify this, al-Faruqi proposes the introduction of "Islamic English." Based on his linguistic diagnosis and remedy, I will discuss this approach from a postcolonial perspective.
\end{abstract}

Keywords: Islam and English, Islamic English, Muslim names, Islamic theological terms, abrogation, appropriation, semantic distortion

\footnotetext{
Md. Mahmudul Hasan (mmhasan@iium.edu.my) is assistant professor in the Department of English Language and Literature, International Islamic University Malaysia. He holds a PhD in feminist comparative literature (University of Portsmouth, 2007) and focuses on postcolonial feminist literature, twentieth-century and contemporary British literature, South Asian literature in English, and Islamic literature.
} 


\section{Introduction}

Since the introduction of English into many Muslim societies by the agents of British colonialism, a large segment of Muslims have had significant reservations about its use as a means of communication in their social and intellectual lives. In the past, many of them deliberately avoided the language as part of their "attitudinal resistance"1 to its cultural associations. Such a stance may have been justified, given the express colonial intent of introducing English into India. According to the oft-quoted statement made in 1835 by Thomas Babington Macaulay (d. 1859), the intent was to produce a comprador class that would be "English in taste, in opinions, in morals, and in intellect" and thus to "refine the vernacular dialects of the country, to enrich those dialects with terms of science borrowed from the Western nomenclature."' Consequently, postcolonial scholars like Kenyan writer Ngugi wa Thiong'o express serious misgivings about its use as an instrument of communication:

[...] language was the most important vehicle through which [colonial] power fascinated and held the soul prisoner. The bullet was the means of the physical subjugation. Language was the means of the spiritual subjugation. ${ }^{3}$

For similar reasons, Muslims also maintained a policy of distance and disengagement:

Being associated with conquest and colonialism, English is seen as inherently inhospitable to Islam and as syntactically and discursively different from any of the major Islamic languages such as Arabic, Persian, Malay, Wolof, or Hausa. ${ }^{4}$

The fact that English is the language of a large segment of the dominant West also contributes to this negative attitude, as the mere mention of it perhaps creates a sense of correlation between the language and its speakers' culture and religion. Another reason for this supposed hostility is the language's general association with the Bible and Christianity in almost the same way that Arabic is thought to be the language of Islam.

For a long time, such perceptions prevented Muslims from learning English. For instance, in the Malaysian context "conversion to Christianity was mainly done through English" and "many Malay and Muslim parents, who hold deeply to Islamic teachings, did not, at the time, want to send their children to English-medium schools." " This held them back in socioeconomic terms. Equally, Muslims in British India were extremely reluctant to receive an English education and therefore lagged behind other indigenous commu- 
nities in the realms of conventional knowledge and prosperity. This political stance harmed the Muslims of India and elsewhere in both intellectual and material terms.

Sensing this predicament, Sayyid Ahmad Khan (d. 1898) launched a powerful movement to introduce English and western education among Indian Muslims. His female successor Rokeya Sakhawat Hossain (d. 1932), the social reformer and foremost Islamic feminist writer of Bengal, carried on this movement and campaigned for English.

About sixty years ago, [our Muslim brothers] were opposed to the study of English even for males; now they are reaping the harvest of their bitter experience. In India almost all the doors to wealth, health, and wisdom are shut against Muslims on the plea of inefficiency. Some papers conducted by Muslims may not admit this - but fact is fact - the inefficiency exists and stares us in the face! ${ }^{6}$

Like Khan and Hossain, contemporary Muslims appreciate the reality that English is an important component of the bridging skills that are so needed when interacting and sharing knowledge across communities. As Amin Malak opines: "Muslim narratives in English prove that the English language, despite all its colonial evocations and its atavistically anti-Muslim connotations, can be utilized as a sophisticated Muslim currency of credible communication." Even if there is still a degree of unease, in the current postcolonial world of transnational and translingual realities such opposition is negligible. For example, both mainstream universities in the Muslim world as well as Islamic universities (e.g., the International Islamic University Malaysia) place enormous emphasis on their students developing a high level of English proficiency. As in most postcolonial countries, in all Muslim nations - even the francophone ones - mastering English is an academic requirement and many Muslim scholars use it to engage in Islamic intellectual practices because of its wider reach across the local and international community.

Interestingly, Hossain did not promote the unmodified, colonial English and English education and its associated cultural assumptions. In fact, she opposed the distortion of Muslim names and the colonized subjects' mimicry of English nomenclature. In one of her speeches, she laments the cultural and linguistic costs engendered by such distortion and regrets that Muslim women exposed to English education have found their names like Laila and Zaynab changed to Lily and Jenny, respectively. ${ }^{8}$ Like Hossain, Ismail al-Faruqi critiques the dominant trend of distorting and mutilating Muslim names via transliteration. He also elaborates upon the semantic loss of Islamic terms 
through inaccurate translations. In order to rectify such situations, he emphasizes the correct transliteration of Islamic/Muslim names, especially those of divine provenance, and the inclusion of Arabic Islamic terms in English, especially in cases where exact equivalents do not exist in the target language. Thus he proposes the creation of a new brand of English, namely, Islamic English, which I will elaborate upon later in this article. At this point, I would like to analyze Islam's encounter with English.

\section{Islam and English}

In general, there seems to be a tinge of antagonism between English and Islam, as well as a supposed correlation between the language and Christianity. This latter association is reinforced by the fact that the appendices of previous editions of the Oxford English Dictionary contain "pictures of the parts of a church and a list of the books of the Bible." Perhaps this explains why many Muslims, although increasingly using English, continue to "sense a strong bond between English and Christianity" 10 and, as an unsubstantiated corollary, a kind of Manichean opposition between the language and Islam.

The supposedly exclusive link between English and the Bible (and Christianity, for that matter) is actually based on a fallacy, because "English is not the language of the Bible: it is the language of an English translation of the Bible." "11 In fact, Hebrew, Aramaic, and Greek are the earlier languages of the Bible, and it took thousands of years for it to be translated (in a real sense) into English. The first edition of the King James Bible was only published in 1611; the Qur'an was translated into English thirty-eight years later in $1649 .{ }^{12}$ Obviously, one reason for this fallacy is that much of the English-speaking world is Christian. But English is also gradually becoming an Islamic language in the same manner, as Malak argues: "English is in the process of being transformed from an Islamophobic to an Islamophile language."13 Thus it may be safely surmised that one day it will also be regarded as the language of Islam mainly due to the following factors: (1) the ongoing huge influx of Muslims, as well as a sharp rise among the indigenous Muslim population, in the West; (2) the growing number of Muslims who are native speakers of English as well as of those who produce their intellectual and creative work in it; and (3) the everincreasing number of English-language publications on Islam and Muslims.

The relationship between Islam as a global religion and English as a transnational and universal language can be compared to what Raja Rao says about English in relation to Indian metaphysics: "Truth can use any language, and the more universal, the better it is. If metaphysics is India's primary con- 
tribution to world civilization, as we believe it is, then must she use the most universal language for her to be universal." ${ }^{14}$ Equally, since in many regions in the West Islam is the second largest and arguably fastest-growing religion, both by birth and by adoption, and since its resurgence is palpable worldwide and affects global affairs, its universal appeal makes the connection between it and English even more pertinent - both are plural and truly global.

In fact, throughout history Muslims have used foreign languages to engage in intellectual pursuits. They dominated the world of knowledge for about a millennium and benefited from other civilizations' intellectual and literary output, much of which scholars translated into Arabic and other supposedly Islamic languages. This long history of learning foreign languages perhaps facilitated their conquest of a highly diverse and vast realm of knowledge spanning various disciplines in languages with which they had no former proficiency. As a result, as James Kritzeck asserts, "throughout Islamic history many of its leading literary figures have been bilingual, and not a few of them have been trilingual." 15 Actually, the rise of a multilingual culture began during the Prophet's lifetime and remains ongoing. For example, the great Islamic polymath and original thinker Abu Rayhan al-Biruni (d. 1048) was conversant with many languages and, with the patronage and sponsorship of Sultan Mahmud Ghaznavi (d. 1030), visited India to study its culture and Sanskrit. He is, in fact, considered "the first non-Indian Sanskritist." ${ }^{16}$ Apart from Persian, Arabic, and Sanskirt, he also learned Hebrew and Syriac. ${ }^{17}$ It would, therefore, be mistaken to mark the beginning of the Muslim world's multilingual culture with the colonial-era introduction of European languages.

Both Islam's theological stance and the Prophet's attitude toward languages support such a syncretistic, vibrant polyglot culture. Although Arabic is the language of the Qur' an and God sent His last messenger to an Arabic-speaking land, Islam does not denigrate other languages. The Qur'an is in Arabic only because its primary audience spoke it: 'Certainly, We have made it a Qur'an in Arabic that you may be able to understand" (Q. 43:3) and "thus We have inspired to you (O Muhammad) an Arabic Qur' an that you may warn (the people of) the mother of the towns (Makkah) and all around it" (Q. 42:7).

These verses proclaim that God chose Arabic so that His message would be clear to its primary audience. Muslims believe that before sending Muhammad, God had sent earlier prophets to other spatiotemporal communities in order to convey His message to them in their own languages: "And We did not send any messenger but with the language of his people, so that he might explain to them clearly [...]'(Q. 14:4). In other words, God chose a specific language mainly to ensure the successful transmission of His message. 
The Qur'an underscores Islam's appreciation of cultural diversity and suggests its recognition of linguistic plurality and cultural heterogeneity: "One of His signs is the creations of the heavens and Earth and the diversity of your tongues and colors" (Q. 30:22) and "O humanity, indeed We have created you of a male and a female, and made you nations and tribes that you may know each other [...]" (Q. 49:13). On the basis of these Qur'anic verses,

It is important to underscore the point that despite the conflict, or discord, as perceived by some Muslims, between Islamic values and some of the Western values as conveyed through English, it is considered desirable, in the Islamic worldview, to learn other languages and to know and appreciate the differences among various communities. ${ }^{18}$

Getting to know each other is possible only when people belonging to different national and cultural backgrounds have a language in common and thus can communicate successfully. Language, which is undeniably the main medium of human interaction at the social level, eventually facilitates and molds social relations. In today's world, due to English's global reach, "people from different parts of the world come to a level of comprehension with one another by using [it] as the medium of communication." ${ }^{19}$ So, given the English language's potential as a global language and a means to communicate with the world, Qur'an 30:22 and 49:13, as mentioned above, can be interpreted as endorsing the importance of any language that is vital for establishing rapport and facilitating accurate understanding among people. Despite the fact that Arabic captures the core of Muslims' intellectual consciousness, it would be wrong to associate Islam exclusively with it. In other words, since Islam is understood to be the religion of all prophets, it cannot be associated with one particular language. Although Muslims must use Arabic to preserve the Qur'an and Hadith literature, ${ }^{20}$ they can use other global languages to engage in intercultural communication and produce both literary and scientific works.

Several hadiths report that the Prophet instructed Zayd ibn Thabit to learn Hebrew and Syriac, the early languages of the Jewish and Christian scriptures, respectively. He did so and thus "came to perform the important function of an interpreter for the Prophet in his dealings with non-Arabic speaking peoples." 21 This practice continued under Prophet Muhammad, for he would send envoys to various language communities to inform them about Islam's teachings in their own language. Salman al-Farsi (Salman "the Persian") a polyglot Companion who knew "Christian scriptures and the Qur' an in addition to his earlier knowledge of the Zoroastrian religion," partly translated the Qur'an into the Persian language. ${ }^{22}$ A detailed biographical study of other Companions may 
reveal the full extent of the multilingual culture that the Prophet established in Madinah. Such a rich, polyglot cultural makeup and traditions of learning and translating continued after the prophetic period. For example, Baghdad's famous Bayt al-Hikmah (House of Wisdom) established by the Abbasid caliph al-Ma'mun in 830, was the "center for translation from Greek, Syriac, and Pahlavi" and the "Mughal royal library in Delhi commissioned extensive translations ... of Sanskrit Hindu literature of all sorts." ${ }^{23}$ As Muslims arguably outdid other contemporaneous religious communities in both scholarship and research, such libraries contained thousands of translated works.

Apart from this theological underpinning, the postcolonial approach to English may remove once and for all the uncertainty and tension between Islam/Muslims and that particular language. Scholars of postcolonial studies have come up with the twin strategies of abrogation and appropriation in order "to interrogate and remake the language of the colonizer." ${ }^{24}$ Through these two simultaneous processes, the vast majority of postcolonial writers have dismantled the hegemonic, universalist assumptions of the language's introduction into the colonies, as they now use it to express their distinctive cultural, religious, and sociopolitical realities, identities, and experiences.

Such a reappraisal invalidates Ngugi's strategy of its outright, compete rejection, as Chinua Achebe asserts "... while Ngugi now believes it is either/ or, I have always thought it was both...."25 As opposed to Ngugi's rejectionist stance, Achebe actually compromises and provides a solution to expurgate the language from its colonial associations. He espouses a process by which English "is made to bear the weight and the texture of a different language." 26 For example, in 1975 he wrote:

I feel that the English language will be able to carry the weight of my African experience. But it will have to be a new English, still in full communion with its ancestral home but altered to suit new African surroundings. ${ }^{27}$

Thus Achebe, like Hossain and al-Faruqi, does not champion a complete capitulation to English or to its colonial undertones; rather, he maintains a strategy of subversion and inversion, which is another way to explicate the notions of abrogation and appropriation.

Abrogation "offers a counter to the theory that use of the colonialist's language inescapably imprisons the colonized within the colonizer's conceptual paradigms [...]. Abrogation implies rather that [...] the same tools offer a means of conceptual transformation and liberation." ${ }^{28}$ Conversely, appropriation refers to "the ways in which post-colonial societies take over those aspects of the imperial culture [...] that may be of use to them in articulating 
their own social and cultural identities." ${ }^{29}$ In other words, the dominant language (English) is adopted, indigenized, and appropriated to describe the experiences of the societies into which it was introduced colonially. In the case of Muslims, these two strategies may mean using English to articulate their ideas without losing their religious and cultural values and practices.

Muslims have adopted a similar approach to engage in intellectual pursuits in English, which makes the relationship between the language and Islam in contemporary times very important. In today's world English is the main conveyer of Islamic knowledge and scholarship, as, perhaps, more books on Islam are being published in it than in any other languages, including Arabic. Nevertheless, as the predominant practice of Muslims suggests, this "countercolonization of English" ${ }^{30}$ has failed to obviate the colonial intent of disseminating "the Western nomenclature" as far as the relationship between English and Islam is concerned. In this respect, al-Faruqi's notion of Islamic English is appropriate and timely.

\section{A Postcolonial Reading of al-Faruqi's Concept of Islamic English}

Like scholars of postcolonial studies, al-Faruqi rejects capitulation to colonial English and seeks to save Muslim names and Islamic terms from possible distortion and semantic loss via transliteration and/or translation. In his Toward Islamic English (1986), he mentions that several hundred million Muslims now use English as the medium of communication in a variety of social, academic, occupational, and other areas. However, he argues, the distortion and mutilation - mainly through transliteration and translation - of Islamic names and words of divine provenance are "chaotic" and constitute "an intellectual and spiritual disaster of the highest magnitude." 31 I will elaborate in more detail upon this below. In short, the way Muslim names and Islamic terms are used in English shows loyalty to the target language (English) and not to the meanings implicit in the source language (Arabic). Needless to say, a cultural loss generally occurs "when words are transmuted from one language to another and subjected to preconceived notions or limitations prevalent in the new language" as "they lose some of their original meaning[s]." ${ }^{\prime 32}$ Al-Faruqi points to this important issue, which has both religious and cultural significance.

\section{Transliteration and the Distortion of Names}

Names and languages are closely associated and can be regarded as interchangeable and synonymous. When we talk about a language, we actually 
refer to a set of names, because the former's principal function is to provide the "names by which the world may be 'known." ${ }_{33}$ Perhaps this is why Macaulay, on the eve of introducing English into India, emphasized the importance of establishing "the Western nomenclature" and refining non-western names and terms accordingly.

In the contemporary world, the ascendancy of the western nomenclature or names is remarkably palpable. In fact, this is one of the most significant aspects of linguistic colonialism, as Bill Ashcroft et al. state:

One of the most subtle demonstrations of the power of language is the means by which it provides, through the function of naming, a technique for knowing a colonized place or people [emphasis added]..$^{34}$

Therefore, the distortion of Islamic names has serious cultural implications. In this respect, al-Faruqi maintains:

Names are often expressive of a whole history, a whole culture, a whole religion, a whole spiritual realm; and it is these which suffer through misrepresentation or misnaming. Should the name be mutilated, disrespectfully bungled or violated, all that it represents is equally violated. ${ }^{35}$

By contesting distortion in the target language, al-Faruqi actually stands against its linguistic hegemony that, either explicitly or implicitly, puts across western associations by twisting and warping Muslim names. Therefore, he argues that "every name should be honored by correct spelling and pronunciation. This is one of the basic human rights of the Muslim." ${ }^{36}$ Postcolonial societies have now revolted against this colonial tendency and are rectifying those names that have been affected. For example, because of their entanglement with British colonialism, "Dhaka" and "Kolkata" were changed to "Dacca" and "Calcutta," respectively; this distortion has now been rectified. Al-Faruqi points to similar distortions with regard to Islamic terms and Muslim names and recommends rectification.

The vast majority of Muslim names carry good meanings or religious significance. When a Muslim baby is born, the parents and relatives search for good names with good meanings. So if they are wrongly transliterated into English, they suffer semantic damage and errors or orthographic mutilation. What is more, most Muslim names have a divine provenance; hence, their incorrect transliteration may be sacrilegious or "next to blasphemy." ${ }^{37}$ Among the examples that al-Faruqi provides are al-Rahman (the Compassionate), Mundhir (a warner), 'Abd al-Ghafur (servant of the Forgiving), and 'Aliyy 
(the High). Al-Rahman is one of the names of God and has immense divine significance, all of which is lost when it is distorted to "al-Rehman" and thus loses its semantic features. Mundhir, a Qur'anic attribute given to the Prophet, means "a warner"; however, if it is written as "Munzir" or "Monzer," the meaning changes to "hurrier," "belittler," or "despiser." When "Abd al-Ghafur is spelled "Abd al-Gafur, its meaning changes to "servant of the wide and empty." Equally, when 'Aliyy is written Aliyy or Ali, it carries a different meaning: "the mechanical." 38

The Prophet's name is, perhaps, the worst casualty of this practice. The Qur'an refers to him as "Muhammad" and "Ahmad" (with the voiceless pharyngeal-fricative " $h$ "). However, common distortions in English are Maumet, Mawmet, Mahound, Mahoun, Mahomet, Mohamet, Mohamed, Mohammed, Mohamad, Ahmed, Ahammad, and Ahammed. The word Muhammad signifies someone who is praiseworthy, and Ahmad signifies someone who praises God the most. Conversely, some of the misnomers bear highly offensive connotations. For example, Mahound stands for a medieval demon and "a cunning and self-seeking imposter" whom Dante "consigned" to Hell. ${ }^{39}$ Al-Faruqi (1986) mentions Webster's International Dictionary's definition of Maumet/Mawmet: "a false god or idol arising from a belief that Mohammedans worshiped images of Mohammed."40 Modern editions of most English dictionaries, fortunately, contain a reasonably better transliteration - Muhammad or Mohammad - even though many of them retain the misspelled and distorted versions as separate entries. As al-Faruqi proposes, it is perhaps time to rectify all of these offensive transliterations invented during periods of intense hostility between Muslims and Christians.

Through the process of transliteration, Arabic Islamic terms have entered Persian, Turkish, Berber, Hausa, Swahili, Somali, Albanian, Kurdish, Uzbek, Tadjik, Pashto, Baluchi, Urdu, Panjabi, Bangla, Gujarati, Sindhi, Telugu, Tamil, Malay, Javanese, Cham, and many other languages.$^{41}$ In the same way, Islamic terms can logically enter English to meet semantic needs, for the inclusion of foreign words in a particular language is a universal requisite. After all, "[s]ome words may not even exist in certain languages because the referents are just not there in the country of the speech community." ${ }^{42}$ Although English has borrowed many words, the rate of borrowing Islamic theological terms from Arabic has been minimal. What is more, most of the Islamic terms found in English dictionaries have been spelled incorrectly to suit the western tongue. Such an approach either mutilates or takes the original words out of context, which then gives rise to totally different meanings. For example, 
transliterating Makkah as "Mecca" involves the risk of destroying its religious connotation because "Mecca" is associated with club activities (e.g., gambling, drinking, and other recreational pastimes). Al-Faruqi contests this cross-linguistic tendency and suggests that it be rectified through accurate transliteration.

\section{Translation of Islamic Terms and the Loss of Meaning}

Closely related to distortion through transliteration is the loss of the original meaning that occurs when translating Arabic Islamic theological terms into English. Al-Faruqi argues:

Many Arabic words are simply not translatable. [...] And when Islamic meanings are altered, transformed and transvalued through translation, it is an irreparable loss to Islam, to the Muslim and to the human spirit. ${ }^{43}$

Even though the Orientalists used "such translations with impunity," al-Faruqi contends, for Muslims to follow them in "their errors and misinterpretations" is "unacceptable." ${ }^{\prime 4}$ Edward Said critiques the trend of representing or understanding foreign terms through the prism of western cultural constructs, for there is "a certain will or intention to understand, in some cases to control, manipulate, even incorporate, what is a manifestly different (or alternative and novel) world [emphasis original]." ${ }^{45}$ A particular word and its meaning are deeply ingrained in the culture from which it originates. In other words, meanings are fundamentally culture-specific, as culture is the breeding ground of a term and determines what it signifies.

Adel Salem Bahameed maintains that the "vocabulary of a language manifests the culturally important areas of a group of people in a particular setting whether religious, aesthetic, social, and environmental, among others. ${ }^{\prime 46}$ Since words and their meanings are ingrained in a specific cultural reality, if the cultural association/s related to a word is/are absent in another linguistic setting, a literal translation of that particular term will miss much of its significance. This problem is more palpable when, in the current dominant practice, Arabic Islamic terms are literally translated into a language - in this case English that lacks accurate equivalents for many Islamic terms. Owning to this crosslinguistic lack, translators tend to temper with the source language text at the expense of its artistic or cultural beauty and thereby convey imprecise meanings and raise post-translation issues over its accuracy. What is more, any mutilation of meaning in the target text constitutes a lasting damage to Islamic scholarship. According to Kritzeck: 
[the] greatest damage of all has been done in the realm of translation: [... and] the treachery which has been perpetrated against Islamic literature by means of translation has been nothing short of monstrous. ${ }^{47}$

The limitation of the target text language and the consequent malpractice in the realm of translation concerning Islamic terms do not suggest that translation is undesirable or that Muslims can ignore its importance. Throughout history translation has facilitated inter-linguistic and inter-cultural communication among peoples of different languages, cultures, and religions. However, a translated work can serve its purpose only if it represents the "form, meaning, and beauty of [the] source text" and "pass [the] same information and should create [the] same effect in target text" as in the source text. ${ }^{48}$

Many Arabic Islamic terms are untranslatable. Al-Faruqi provides some examples, among them șalāh and zakah, to show how their mistranslation distorts their intended meanings and thus gives rise to semantic impairment, ambiguity, bias, or confusion. He argues that șalāh has very specific connotations, such as that it

must be held at its five [decreed] times, [...] should consist of precise recitations, genuflections, prostrations, standings and sittings with orientations towards the Ka'bah, and should be entered into only after ablutions and a solemn declaration of intention or niyyah. ${ }^{49}$

However, translating it as "prayer" conveys few of these associations, as the act of "prayer" in English can be to God, to any deity, idol or even to any human being. Equally, zakah is

more of the nature of a public welfare tax, with the specific amount of $2 \frac{1}{2}$ per cent of appropriate wealth beyond a certain minimum amount [...]. Its payment is religiously and publicly obligatory for all Muslims [...]. [It] is a "sweetening" of the total income of the year and of the owner's continued holding of accumulated wealth. ${ }^{50}$

Most of these meanings are lost when it is simply translated as "charity, alms, poor-due, or alms-giving" because zakah "is not the equivalent of any" of these words. ${ }^{51} \mathrm{Al}$-Faruqi mentions other Islamic terms, like "taqwā, huda, daläl, qist, wahy, șiyām, hajj, fiqh, ușül al-fiqh, hadith, etc.," all of which have a much wider "meaning in their Arabic form than English approximations are ever capable of carrying." 52 In the light of this view, I randomly choose and discuss below several other important Arabic Islamic terms and argue that their usual literal translations run the risk of erasing their finer cultural and 
religious nuances or of wrongly associating them with culturally dissimilar symbols or conceptual domains.

The term islām is generally translated into English as "peace," "surrender," or "submission." In English, however, submission carries "a sense of coercion, a usurpation of one's free will," while surrender is associated with a gunpoint confrontation or a hostage situation. Actually, the Arabic word for surrender is istislām, as one of its derivatives occurs in the Qur'an: "Nay, but this day they make full submission" (Q. 37:26). A single-word translation of islām may not be possible, as no single English word can capture its meaning along with all of its associative features. In fact, islām signifies a special context of a person's relationship with God, one in which free will is a core component. No one can force or coerce an individual or a community to embrace Islam, for the Qur'an proclaims unequivocally: "Let there be no compulsion in matters of faith" $(\mathrm{Q}$. 2:256). Interestingly, in Arabic both islām and istislām are derived from the same primary root, $s-l-m$, and have an "etymological relationship" that "is critical and cannot be lost in translation": Muslims "submit willingly to God in search of peace." ${ }^{53}$ This submission or surrender is voluntary; however, once a person enters Islam he/she must seek to understand and carry out its principles. Regrettably, this concept and correlation of freedom and peace is lost when islām is translated only as "surrender/submission" or simply as "peace."

The Islamic term jihād is widely translated as "holy war," a distortion that gives one the impression that Islam, as a religion, is hostile and belligerent. The website thefreedictionary.com provides a tertiary definition that is perhaps the most accurate in terms of meaning: "3. A crusade or struggle: "The war against smoking is turning into a jihad against people who smoke." Brown (1996) supports this definition, as the "Cambridge [English Dictionary] defines crusade as 'a long and determined attempt to achieve something which you believe in strongly." "54 This is the closest to what jihad suggests.

"Cleanliness/purity" and "uncleanliness/impurity" do not carry the whole thrust of what tahārah and najāsah, respectively, signify. For example, these English words do not necessarily involve the state of ritual impurity after a couple engages in sexual intercourse. In the same way, tahärah does not simply point to removing dirt, for, according to Islamic jurisprudence, it also suggests that people should purify themselves in a prescribed manner and must state their niyah (intention) before doing so. Needless to say, some forms of tahärah require washing the body, which is not necessarily the case with cleanliness/purity.

The Islamic jurisprudential term "iddah is commonly translated as "a waiting period," which does not convey its full significance: a specific length of 
time that a widowed or divorced woman must wait before remarrying. An even more inaccurate translation is a "period of confinement/seclusion," for this term has absolutely nothing to do with confinement or seclusion. The word $k u f r$ has two aspects: ingratitude and disbelief. It actually means "[i]ngratitude to God and manifest disbelief in Him and His religion." 55 Translating it as disbelief, unbelief, irreligion, or infidelity does not adequately signify the original term's twin shades of meaning.

These random examples substantiate al-Faruqi's argument and show that many Islamic theological terms cannot be literally translated without compromising with their religious associations and subtle shades of meaning. This is hardly surprising because English, like all languages, has its own limitations and lacks the appropriate terms to render fully the underlying semantic meanings of many Islamic expressions. Therefore, al-Faruqi proposes that all such Islamic terms be incorporated into English verbatim, along with their various definitions and connotations, to maintain their original flavor. In other words, to ensure definitional clarity and prevent semantic loss and obfuscation, the compilers of English dictionaries should include more Islamic Arabic terms.

In fact, English has been borrowing Arabic words for centuries, and many Arabic terms have already been incorporated "through everyday use among merchants and travelers as well as through science and learning." 56 For instance, quoting from Webster's Third International Dictionary, Muhammad Uraif provides a list of Arabic words that have entered English with little or no distortion: admiral (amīr al-bahr), alcazar (al-qașr), alcohol (al-ghawl), algebra (al-jabr), algorithm (al-khawarimsî), almanac (al-manākh), apricot (barkūk), cable (habl), camel (jamal), candy (qandī), carat (qirāt), coffee (qahwah), cotton (qutn), gazelle (ghazāl), giraffe (zaräfah), jar (jarrah), jasmine (yasmīn); lemon (laymūn), lime (lìm); magazine (makhāzin), massage (massa), mattress (mafrash), safari (safārî), sesame (simsim), sugar (sukkār), syrup (sharab), tariff (ta 'rîf), zenith (samt), and zero (șifr). ${ }^{57}$

Most of these adopted Arabic terms are non-religious and largely related to science, trade, food, spices, commodities, the military, animals, and other non-theological domains. Al-Faruqi attributes this to the fact that in the past Arabic was the "world language of science and technology, of administration, of international relations and trade." 58 Thus when the Europeans replaced the Arabs in advancing these areas of knowledge, they needed the relevant, existing Arabic vocabulary and so borrowed whatever they needed without any reservation. Conversely, as mentioned before, Arabic Islamic terms were not adopted due to religious and cultural prejudices. The handful of Islamic religious terms - such as ayatollah, hajj, halal, jihad, mujahideen, Shia, Sunni 
- that are found in English dictionaries are recent entries to an already very short list. Needless to say, some of them are wrongly defined. Hence, al-Faruqi proposes the use of Islamic English to ensure the correct and inoffensive use of Islamic names and expressions in terms of transliteration, translation, and linguistic referrals.

In the context of English as a global language, his analysis of the usage of Islamic theological terms is quite pertinent, as it helps create awareness among academics of the appropriate usage while transliterating or translating such terms. This facilitates the currency of a new (Islamic) English that modifies the rendering of Islamic-Arabic idioms into English and enables "it to carry Islamic proper nouns and meanings without distortion, and, thus to serve the linguistic needs of Muslim users of the English language. ${ }^{59}$

\section{The Feasibility of Islamic English}

Postcolonial scholars believe that there is "a range of 'Englishes,' each with its distinctive history and characteristics, such as American English, British English, Canadian English, Indian English, Irish English, New Zealand English, Malaysian English, Nigerian English, Singapore English, and Zimbabwean English." ${ }^{\prime 60}$ Obviously, this emergence of multiple Englishes first started in western countries and then, in order to represent their cultural and linguistic varieties, was adopted by writers from non-western societies as a strategy to indigenize the language. As Rao states regarding Indian English: "Our method of expression therefore has to be a dialect which will some day prove to be as distinctive and colorful as the Irish or the American." ${ }^{61}$ Although Islam is not a geographical entity, it binds Muslims with shared cultural and religious traditions, beliefs, values, norms, heritage, history, identity, and so on. All Muslims share many common Arabic religious terms, which necessitates the emergence of an Islamic English capable of conveying accurate Islamic semantic nuances and specificities.

One important aspect of this variety is the inclusion of Islamic terms in English dictionaries, especially when "a corresponding TL [target language] equivalent for the SL [source language] item"62 is unavailable. This is hardly impossible, given the history of English-speakers borrowing words from other languages. Al-Faruqi states that in pre-modern times words were borrowed from Latin and Greek and, in modern times, from French, German, Spanish, Italian, and other European languages. ${ }^{63}$ In today's world, foreign words are entering English and enriching it on a regular basis. Thus incorporating Islamic terms is "not really a violation of English. Rather, it is an enrichment." 64 
In the mid-twentieth century there were about 500,000 English words; by the turn of the century this number had doubled. In 2009, it reached the threshold of 1 million. The Oxford English Dictionary also contains "about 600,000 words (mostly drawn from written sources)" and adds "more than 1,000" new words annually. ${ }^{65}$ According to Paul J. J. Payack, president and chief word analyst of the Global Language Monitor, this rapid increase has been possible because of "an amazing ability" of the language "to accept new words" massive and ongoing scale. However, the borrowing of Arabic Islamic theological terms has not taken off yet, despite the impressive openness of English to foreign influences and despite the semantic need to include them. Given the language's commendable ability and tendency to welcome foreign words, it should not be a problem to include Islamic theological terms in a democratic manner in order to protect them from semantic distortion.

Obviously, the rate of such inclusion is comparatively low due to a particular historical reason: "During the thirteenth centuries of their particular coexistence, Islam and Christendom have exhibited astonishingly little intellectual curiosity about one another." ${ }^{167}$ However, in the current world the "spiritual and intellectual tyranny of the [Catholic] Church," which in the past prevented Islamic terms from entering English or Latin-based languages, has been greatly diminished. ${ }^{68}$ As a result, the interactions between the English-speaking West and the Islamic world have greatly increased, a development that may facilitate the introduction of many Islamic terms, provided that Islamophobia does not affect this natural process of borrowing words.

As mentioned earlier, semantic distortion is quite common during the process of translation. However, it may be an incorrect and overgeneralized statement to say that all English-language etymologists intentionally engage in this activity of distortion. In fact, one major reason for this is their lack of knowledge about Islam and its culture.

\section{The Muslims' Role}

Brown compares the quality of translation as well as the rate of distortion by analyzing the translations of Arabic Islamic terms found in four English dictionaries - Oxford, Longman, Cobuild, and Cambridge. He shows that the Cobuild dictionary is relatively better in terms of providing "good definitions" because it "was researched at the University of Birmingham, a British city with a large Muslim population." ${ }^{69}$ In other words, this splendid difference is due to the Muslim presence in the city. This suggests that if competent Muslims do not come forward to rectify these distortions and inform English-language ety- 
mologists of their mistakes, it may take a very long time for non-Muslim scholars, who have not been adequately exposed to Islamic teachings or the Arabic linguistic order, to even realize that such inaccuracies exist. In this respect, Brown cites two examples: The first edition of the Longman Dictionary of the English Language and Culture described Bangkok as a place often associated with prostitutes. The Thais objected, and the definition was promptly revised. Likewise, Microsoft's multimedia Spanish dictionary described Indians as savages. Again, this was changed as the result of protests. ${ }^{70}$

This suggests that scholars of Islam, both Muslim and non-Muslim, may need to engage in the discussion and work to ensure the correct rendition of Islamic terms. An investigation and possible rectification of inaccurate translations will lead to a similar exercise with regard to other non-Arabic (especially European) languages, "because the rules regarding translation apply to all, and the rules applying to transliteration apply to those languages which are written in the Latin alphabet." 71 Thus one can say that al-Faruqi's concept of Islamic English has far-reaching implications and cross-linguistic applicability that can guide the correct usage of Islamic terms in major world languages.

\section{Conclusion}

The spread of English among Muslims and the spread of Islam among speakers of English are simultaneous and synchronous. Despite the Muslims' historical aversion to learning English, this particular language is increasingly becoming an Islamic one. The huge influx of Muslims into English-speaking countries is bringing both the Arabic and English languages as well as the Muslims and Judeo-Christian faith communities into ever-closer contact. In such a context, Muslims' use of English in everyday life and intellectual pursuits has reached a phenomenal stage. The rapprochement between Islam and English is perhaps more evident in today's world than it was in 1986, when Toward Islamic English was first published. All this makes the discussion more pertinent and timely, and the evolution of a vibrant, new variety of English more likely. Under the circumstances, the proposition of Islamic English has the potential to generate intense intellectual interest.

The sense of hostility between Islam and the English-speaking Christian world is not as flagrant now as it was roughly a century ago, even though a neocolonial entanglement between the West and the Muslim world can still be witnessed in various cultural and political practices. The emergence of a growing liberal intelligentsia in the West may defy civilizational rivalry between Islam and the English-speaking world and thus facilitate the beginning of the new variety of Islamic English. 
The crux of this essay's argument is the need to protect Arabic Islamic terms from distortion when transliterating or translating them into English. And this is possible if, like terms from other languages, they are allowed in without the loss of their various shades of meaning. The overarching wave of postcolonial theories stressing the preservation of cultural and linguistic distinctiveness of non-western traditions further strengthens the argument of having a new brand of English, namely, Islamic English. This postcolonial tendency substantiates al-Faruqi's idea that Muslim names and Islamic theological terms can enter English without semantic distortion and continue to enrich this now truly global language.

Since the variant linguistic realities of different cultures call for varieties of English or world "Englishes," the distinctive features of Islamic culture and scholarship necessitate the emergence of this brand of English. Given the putative opposition between Islam and English, which may apparently render the term Islamic English oxymoronic, there are complexities as well as possibilities of such a new form of English. At present, differences in cultural and religious associations belonging to Arabic and English prevent a number of Arabic Islamic terms from being translated accurately due to the lack of appropriate functional or intercultural equivalents. In such cases, literal translations may cause a loss of meaning. To minimize the ensuing distortion, all speakers of English may need to use the original Islamic religious terms instead of trying to find or devise equivalents. This will gradually smoothen their entry into English dictionaries and thus into its vocabulary.

The magnitude of the linguistic obstacles to the proper understanding of Islamic expressions, the accompanying cultural damage, and the loss of many of the semantic and associative features of Islamic theological terms is very high due to incorrect spelling and transliteration and mistranslation. This is not only a theological problem, but also a linguistic impediment to the correct appreciation and understanding of Islamic culture, which, according to Kritzeck, is "unquestionably one of the greater cultures in the history of mankind and of the world today." 72 This continued mutilation and distortion constitutes a regrettable loss in regard of Islam's cultural and intellectual contributions, for it diminishes the richness of the world's collective body of knowledge as well as its linguistic and semantic heritage. In his Toward Islamic English, Ismail alFaruqi proposes that semantic justice can be achieved by introducing an "Islamic English" that can transliterate and defind Islamic terms and symbols within their original Islamic context. This article corroborates this approach, especially from a postcolonial perspective. 


\section{Endnotes}

1. Ratnawati Mohd-Asraf, "English and Islam: A Clash of Civilizations?” Journal of Language, Identity \& Education 4, no. 2 (2005): 103-18, 104.

2. Qtd. in Barbara Harlow \& Mia Carter, ed., Archives of Empire Volume I: From East India Company to the Suez Canal (Durham, NC: Durham University Press, 2003), 237.

3. Ngugi wa Thiong'o, "The Language of African Literature" [1981], in Bill Ashcroft, Gareth Griffiths, \& Helen Tiffin (Ed.), The Post-Colonial Studies Reader (pp.263-67) (London: Routledge, 2006), 265.

4. Amin Malak, Muslim Narratives and the Discourse of English (New York: State University of New York, 2005), 2.

5. Mohd-Asraf, "English and Islam," 109.

6. Rokeya Sakhawat Hossain, "God Gives, Man Robs" [1927], in Abdul Quadir (Ed.), Rokeya Rachanabali (2d ed.) (pp. 477-78), (Dhaka: Bangla Academy, 2006), 491.

7. Malak, Muslim Narratives, 7.

8. Hossain, "Dhongser Pathe Bongio Mussalman" [The Bengal Muslims on the Way to Decline, 1931], in Abdul Quadir (Ed.), Rokeya Rachanabali (pp.24447), 245.

9. Adam Brown, "The Treatment of Religious Terminology in English Dictionaries," in Jalal Uddin Khan \& Adrian E. Hare (Ed.), English and Islam: Creative Encounters (pp.307-14). (Kuala Lumpur: International Islamic University Malaysia, 1996), 309.

10. Gbenga Fakuade, "Lingua Franca from African Sources in Nigeria: The Journey So Far," Language Problems \& Language Planning 18, no. 1 (1994): 38-46, 44.

11. Brown, "The Treatment of Religious Terminology," 309.

12. Abdullah Saeed, The Qur'an: An Introduction (London: Routledge, 2008), 122.

13. Malak, Muslim Narratives, 8.

14. Qtd. in Braj B. Kachru, "The Alchemy of English" [1990], in Ashcroft, Griffiths, and Tiffin, eds., The Post-Colonial Studies Reader (pp.272-275), 274.

15. Kritzeck, "Introduction," in James Kritzeck (Ed.), Anthology of Islamic Literature: From the Rise of Islam to Modern Times (pp.15-27). (New York: New American Library, 1964), 15.

16. Freda Shamma, ed. Treasury of Muslim Literature: The Golden Age 750-1250 CE (Beltsville, MD: amana publications, 2012), 167.

17. Camilla Adang, Muslim Writers on Judaism and the Hebrew Bible: From Ibn Rabban to Ibn Hazm (Leiden: E. J. Brill, 1996), 58.

18. Mohd-Asraf, "English and Islam," 115.

19. Ibid., 107.

20. Hadith is the written record of the oral traditions of what Prophet Muhammad said, did, or approved. 
21. N. K. Singh, Prophet Muhammad and His Companions (Delhi: Global Vision, 2003), 384.

22. Ibid., 308.

23. George M. Eberhart, ed., The Whole Library Handbook 4: Current Data, Professional Advice, \& Curios, Chicago: American Library Association, p.504.

24. Julie Mullaney, Arundhati Roy's The God of Small Things: A Reader's Guide (New York: Continuum, 2002), 64.

25. Chinua Achebe, "The Politics of Language" [1989], in Ashcroft, Griffiths, and Tiffin (Ed.), The Post-Colonial Studies Reader (pp.268-271), 268.

26. Ashcroft, Griffiths, and Tiffin, The Post-Colonial Studies Reader, 262.

27. Qtd. in Ania Loomba, Colonialism/Postcolonialism, 2d ed. (London: Routledge, 2005), 80.

28. Bill Ashcroft, Gareth Griffiths, and Helen Tiffin, Post-Colonial Studies: The Key Concepts (London: Routledge, 2000), 5.

29. Ibid., 19.

30. I have borrowed this term from Alfred Yuson, "Filipino Diasporic Literature," in Philippine English: Linguistic and Literary Perspectives, ed. Maria Lourdes S. Bautista and Kingsley Bolton, (pp.337-56) (Hong Kong: Hong Kong University Press, 2008), 347.

31. Ismail Raji al-Faruqi, Toward Islamic English (Herndon, VA: International Institute of Islamic Thought, 1986), 8.

32. Ahmed Rehab, "Language Matters: Islam, a Definition," Chicago Tribune, November 4, 2010, retrieved on October 16, 2013 from http://newsblogs.chicagotribune.com/religion_theseeker/2010/11/language-matters-islam-a-definition.html

33. Ashcroft et al., The Post-colonial Studies Reader, 261.

34. Ibid.

35. Al-Faruqi, Toward Islamic English, 9.

36. Ibid., 8 .

37. Ibid., 9 .

38. Ibid.

39. Bernard Lewis, The Arabs in History (New York: Oxford University Press, 2002), 45.

40. Al-Faruqi, Toward Islamic English, 10.

41. Kritzeck, "Introduction," 16.

42. Haja Mohideen Bin Mohamed Ali, "Towards an Islamically Appropriate Alternative Vocabulary in English," in Jalal Uddin Khan, and Adrian E. Hare (Ed.), English and Islam: Creative Encounters (pp.389-394) (Kuala Lumpur: International Islamic University Malaysia, 1996), 389.

43. Al-Faruqi, Toward Islamic English, 11.

44. Ibid.

45. Edward Said, Orientalism: Western Conceptions of the Orient (New York: Penguin, 1978), 12. 
46. Adel Salem Bahameed, "Hindrances in Arabic-English Intercultural Translation," Translation Journal 12, no. 1 (2008), retrieved on April 25, 2011, from http://translationjournal.net/journal/43culture.htm.

47. Kritzeck, "Introduction," 19.

48. Asma Abd-Allah Halahla, "Problems in Translating Islamic Text from Arabic into English" (n.d.) retrieved on April 25, 2011, from http://www.scribd.com/ doc/30772708/Arabic-English-Translation-of-Islamic-Text.

49. Al-Faruqi, Toward Islamic English, 11.

50. Ibid., 12.

51. Ibid.

52. Ibid.

53. Rehab, "Language Matters: Islam, a Definition."

54. Brown, "The Treatment of Religious Terminology," 311.

55. Halahla, "Problems in Translating Islamic Text."

56. Muhammad Kheder Uraif, "The Importance of Arabic: Mother Tongue of Islam and Its Impact on Western Knowledge and Culture," in Supporting Cultural Differences through Research (pp.797-805) (2001), 801 retrieved on Oct. 16, 2013 from http://s3.amazonaws.com/academia.edu.documents/30885256/2011monograph2.pdf?AWSAccessKeyId=AKIAIR6FSIMDFXPEERSA\&Expires=1381 968819\&Signature $=\mathrm{d} \%$ 2BwUoF2TCnNWiSP4Av9xjZJVXeA\%3D\&responsecontent-disposition $=$ inline $\#$ page $=806$.

57. Ibid., 801-02.

58. Al-Faruqi, Toward Islamic English, 12.

59. Ibid., 7.

60. Thomas Burns McArthur, The English Languages (Cambridge: Cambridge University Press, 1998), xiv.

61. Raja Rao, "Language and Spirit" [1937]. In Ashcroft, Griffiths, and Tiffin (Ed.), The Post-Colonial Studies Reader (276), 276.

62. Bahameed, "Hindrances in Arabic-English Intercultural Translation."

63. Al-Faruqi, Toward Islamic English, 12.

64. Ibid.

65. Jennifer Schuessler, "Keeping It Real on Dictionary Row," New York Times ((June 13, 2009) retrieved on 17 Oct 2011 from http://www.nytimes.com/2009/ 06/14/weekinreview/14shuessler.html.

66. Qtd. in ibid.

67. Kritzeck, "Introduction," 17.

68. Al-Faruqi, Toward Islamic English, 13.

69. Brown, "The Treatment of Religious Terminology," 314.

70. Ibid., 313.

71. Al-Faruqi, Toward Islamic English, 7.

72. Kritzeck, "Introduction," 15. 